\title{
Research on Influence Factors and Formation Mechanism of Government Trust: Based on Survey Data of Colleges and Universities in Baoding
}

\author{
Zheng-tao PENG \\ The second Campus of North China Electric Power University \\ Baoding, Hebei, China
}

Keywords: Political Trust; Social Trust; Gossip; Government Performance.

\begin{abstract}
According to a questionnaire survey of university students in Baoding, This paper investigated the degree of trust of Chinese college students in the government, and further analyzed various factors affecting the trust of university students. The impact of grapevine news, authoritarian values, government performance, and related factors on the trust of residents has been explored based on match correlation analysis. Finally, it proposes some ways of improving government work and improving social capital to increase the trust of college students in the government.
\end{abstract}

\section{Introduction}

On March 18, 2014, General Secretary Xi Jinping spoke at an expanded meeting of the Standing Committee of the Lan kao County Committee of Henan Province about such an important political concept as the Tacitus Trap. This reflects the major thinking of the new leadership of the central leadership on the issue of the government's popular support. The concept of "Tacitus Trap" reflects the problem of government trust. Government trust refers to people's confidence and support for the government, a thermometer for government performance, and an important social psychological foundation for political development. A stable, sustained and high level of trust helps to improve the legitimacy and effectiveness of the government and establish a close relationship between the government and the public. In the context of the end of more than 30 years of rapid economic growth into the "new normal" and the continued high pressure of the anti-corruption struggle, how has the public's support for the government changed? What is the current situation? How to explain these phenomena has become an important and urgent practical and theoretical issue.

At present, China's higher education has entered the new normal of coordinating the "socialist" school-running direction and the "modernization" school-running level and building a modern university with Chinese characteristics. Under the new normal, it is necessary to upgrade the quality of higher education. It is also necessary to cultivate the socialist core values of university students and ensure their confidence and belief in the cause of socialism with Chinese characteristics. A stable, reliable, and high-level political trust helps college students establish and maintain socialist core values, thereby ensuring the direction of university education. Deng Xiaoping emphasized that "There is no doubt that schools should always put the correct and correct political orientation in the first place." "Strengthen political education, situation education and ideological education at all levels, including life outlook education and moral education." Political trust refers to the belief and confidence of college students that the government can operate according to their expectations.

On this basis, the paper put forward the research hypothesis:

Hypothesis A: Social capital has an impact on the political trust of college students

Inference A: Authoritarian values have a positive and relevant influence on the political trust of college students.

Hypothesis B: Sources of Information Have an Impact on College Students' Political Trust

Inference B-1: Positive correlation between official news and college students' political trust

Inference $B-2$ : The relationship between grapevine information and college students' political trust is negatively correlated.

Overall, when researchers use the concept of "political trust", their statements are not consistent, 
but there is no difference in the nature of the concept. It is only that the context is different from the definition of "government". Different countries have different political and political interests, sometimes referring to administrative agencies ("small government"), sometimes including legislation and the judiciary ("big government"). The concepts of "political trust" and "government trust" are also often mixed. The broad "government" includes the entire government agency system ("big government"), but also civil servants (officers, members, etc.). Therefore, the broad sense of "government trust" is equivalent to "political trust". In the unique context of China, the object of political trust includes not only government agencies and civil servants, but also the party's organizational system and the official media subordinate to the propaganda department.

\section{Research on Factors Influencing University Students' Political Confidence}

\subsection{Personal factors}

Wang Zhengxiang (2009) found that among the university students' demographic factors (gender, age, household registration, family per capita income, father's education level, Party membership), only age has a significant impact - the greater the age, the lower the political level [1].

\subsection{Media factors (for political socialization and performance evaluation)}

Wang Zheng xiang's (2009) study shows that the overall use of print media by college students has a positive impact on their political trust, but the overall use of online media has a negative impact on their social and political trust [1].

\subsection{Simply divided the dependent variable and the independent variable.}

In the relevant variable setting, the government trust level was measured in this study. In the measurement of the governments at all level, the Party Central Committee, the State Council, the provincial Party committee and the province were selected. The government, the municipal Party committee and the municipal government, the fiber and the county government, the township Party committee and the township government, and the village committees, the governments of the six different levels, the trust values between these seven different levels of government were compared. At the same time, the central government was transformed into a large government, the remaining six levels of government were transformed into local governments, and the trust level of local governments and the central government were compared. In the measurement of the trust level of the government, five representative topics are selected, and a mean treatment is finally performed. See Table 1 for the source and design details of these three independent variables.

Table 1. Political trust scale

\begin{tabular}{l|l|l|l}
\hline Variable & Mean & Min & Max \\
\hline Government trust level & 3.422 & 5 & 1 \\
\hline Official message & 2.635 & 5 & 1 \\
\hline Institutional performance & 3.2525 & 5 & 1 \\
\hline Authoritative values & 2.194 & 3 & 1 \\
\hline Trail news & 1.805 & 3.5 & 1 \\
\hline
\end{tabular}

In the dependent variable political trust measurement, this study built these five topics into a political trust scale (see Table 1 for details). Add up the scores of the five questions and then average them to obtain the final political confidence of the college students. The division of degree of trust is as follows 0 to 1 is divided into very untrustworthy, greater than 1 is less than or equal to 2 is distrusted, 2 to 3 is divided into comparative trust, 3 to 4 is divided into trust, and 4 to 5 is trustworthy.

Table 2. Government trust level

\begin{tabular}{l|l|l|l|l|l|c}
\hline Variable & Obs & Mean & Std. & Dev. & Min & Max \\
\hline Government trust level & 200 & 3.42 & 2.71 & 72785 & 1 & 5 \\
\hline
\end{tabular}


From the measurement results, the contemporary college students' trust in the government is generally at a high level. Nearly $80 \%$ of college students agree with the government as a whole, and the government and its distrust are not shown in the sample of this study. More than $10 \%$ of college students agree with the government very much, and a relatively small number of people who disagree. Through calculation, it can be known that the trust level of the university student government is 3.422 , which is generally at the level of trust.

\section{Match Correlation Analysis}

Table 3. The Correlation between variables and government trust

\begin{tabular}{l|l}
\hline & Government trust level \\
\hline Institutional performance & $0.4862^{*}$ \\
\hline Trail message & $-1.265^{*}$ \\
\hline Official message & $0.2757^{*}$ \\
\hline Authoritative values & $0.4702^{*}$ \\
\hline
\end{tabular}

At the same time, it can be seen from the Table 3 that the correlation coefficient between authoritarian values and political trust is $0.4702 *$. This also confirms the inference A: authoritarianism has a positive correlation on the political trust of college students.

Meanwhile, the correlation coefficient between official news and political trust can be found in the Table 3 is $0.2757^{*}$. This confirms the inference B-1: the relationship between official news and the political trust of college students is positively correlated.

From the Table 3, it also can be found that the correlation coefficient between grapevine information and political trust is $-1.265^{*}$. This shows that the more accepted gossip messages, the more distrust the government has. This also verifies the previous inference B-2: the relationship between grapevine information and college students' political trust is negatively correlated.

\section{Results and Discussion}

The influence of authoritarianism on the political trust of college students is mainly reflected in the universal trust in authoritarianism and social trust. Authoritarianism has a positive and related influence on the political trust of college students, and general trust and political trust are negatively correlated. Authoritarianism is still an important value concept that dominates people's behavior for East Asian countries. Authoritarianism is prevalent among college students today.

The more the gossip, the lower the government trust; the more formal news, the higher the government's trust; therefore, the source and quantity of the news will affect the degree of government trust.

\section{Suggestions}

In the basis of the results and discussion of the study, the researcher proposed several practical suggestions for government, society and further researches.

\subsection{Make scientific decisions, improve the implementation process of policies and improve the effectiveness of implementation}

The formulation of the government's people's livelihood policy should reflect the views and interests of the broadest masses of the people. Otherwise, the government will lack a basis for rationality, and at the same time it will also affect the feasibility and effectiveness of the policy. For example, a public opinion survey system can be established, and public opinion surveys must be conducted prior to the introduction of major government policies. The government must establish a sound hearing system. Although the hearing system has been implemented in the government's public decision-making, there are still problems such as the low level of standardization, the large interference by strong interest groups and human factors, and the lack of an equal-playing game 
platform. The government should also establish a citizen evaluation and supervision system to supervise the implementation of policies so that citizens can truly exercise their power and become true masters. The government should respond to the evaluation and supervision of the public in a timely manner, openly evaluate and supervise the results, and avoid embarrassing evaluation and supervision. Open and transparent governments and policies will inevitably increase their credibility.

\subsection{Standardize the media environment and reform the ideological and political education model in colleges and universities}

College students have strong plasticity, and their political trust is greatly influenced by media propaganda and education. At present, the society has entered the era of self-media. College students have access to a variety of massive information through the Internet and mobile phones. There are a lot of unilateral and false information. If they are not regulated, they will have a negative impact on the political trust of college students. Therefore, we must first regulate the media environment, especially to strengthen the management of online media, effectively guide public opinion, create a positive and healthy public opinion environment, $100 \%$ information disclosure, timely release, provide information to grasp the initiative, and give full play to resource advantages. Focus on social hotspot issues and take the initiative to guide the direction of public opinion. Respond to bad information in a timely manner, and defeat the gossip with authoritative information. Second, we must reform the methods, methods and content of ideological and political education in colleges and universities. The current college students pay more attention to practical problems. There are many sources of information, and the amount of information they hold is large. However, traditional teaching methods and means are simple in form, and the amount of information is very limited. It is far from meeting the needs of contemporary college students' ideological education. Ideological and political education should be based on college students, pay attention to the effectiveness of education, and adopt flexible and diverse educational methods such as social practice to stimulate the enthusiasm of college students to participate in the application of modern information technology such as Weibo to help students understand the national conditions. We should cultivate the sense of social responsibility and collectivism of college students who love the motherland and the people, and increase their political trust in the party and the government.

\subsection{Improve the mass media management system and promote the effective operation of the mass media}

With the rapid development of science and technology, mass media tools have been continuously upgraded, and the media channels have been constantly updated, especially the popularity of the Internet, so that college students are surrounded by a large amount of information every day. However, at present, some media have neglected professional ethics in order to obtain economic benefits and intended to increase negative reports on news events; some media did not take active actions and lacked timely and effective supervision over the political system and its operational status; some media were alienated into Western countries to carry out cultural erosion in China and to promote capitalist political ideas. As the management system of China's mass media is not yet perfect, there is no effective response to the unreasonable phenomenon of mass media in the process of operation, coupled with the lack of adequate social experience and good discriminating abilities among university students, political emotions and political positions. Instability, the political psychology and political behavior of contemporary Chinese college students have been adversely affected by the mass media to varying degrees, and their level of political trust has been greatly affected. Therefore, if we want to create the political trust of college students, we must establish and improve the mass media management system, promote the effective operation of mass media, give full play to its positive role, and overcome its negative effects.

\section{References}

[1] Wang Zhengxiang. Research on the Influence of Media on College Students' Political Trust and 
Social Trust [J]. Youth Research, 2009, 02: 64-74+96. (In Chinese)

[2] Liu Yanxian. Contemporary China's political trust and its cultivation [J]. Journal of China Pudong Cadre Institute, 2009, 04: 57-60. (In Chinese)

[3] Li Guiying. College students' political trust structure and causes [J]. Contemporary Youth Research, 2011, 05: 43-46. (In Chinese)

[4] Wang Xiangmin. "U” Distribution: The Structural Distribution of China's Political Trust [J]. Journal of China Pudong Cadre Institute, 2009, 04: 69-72. (In Chinese) 